ARTICLE

https://doi.org/10.1038/s41467-019-11543-9

\title{
Marked isotopic variability within and between the Amazon River and marine dissolved black carbon pools
}

\author{
Alysha I. Coppola (10 1, Michael Seidel (10 2, Nicholas D. Ward (10 3,4, Daniel Viviroli (1) 1, Gabriela S. Nascimento ${ }^{1,5}$, \\ Negar Haghipour ${ }^{5,6}$, Brandi N. Revels ${ }^{5}$, Samuel Abiven (1) ${ }^{1}$, Matthew W. Jones ${ }^{7}$, Jeffrey E. Richey (1) ${ }^{4}$, \\ Timothy I. Eglinton (1) ${ }^{5}$, Thorsten Dittmar (i) ${ }^{2,8} \&$ Michael W.I. Schmidt (1) ${ }^{1}$
}

Riverine dissolved organic carbon (DOC) contains charcoal byproducts, termed black carbon (BC). To determine the significance of $\mathrm{BC}$ as a sink of atmospheric $\mathrm{CO}_{2}$ and reconcile budgets, the sources and fate of this large, slow-cycling and elusive carbon pool must be constrained. The Amazon River is a significant part of global BC cycling because it exports an order of magnitude more $D O C$, and thus dissolved $B C(D B C)$, than any other river. We report spatially resolved $D B C$ quantity and radiocarbon $\left(\Delta^{14} C\right)$ measurements, paired with molecular-level characterization of dissolved organic matter from the Amazon River and tributaries during low discharge. The proportion of $\mathrm{BC}$-like polycyclic aromatic structures decreases downstream, but marked spatial variability in abundance and $\Delta^{14} \mathrm{C}$ values of DBC molecular markers imply dynamic sources and cycling in a manner that is incongruent with

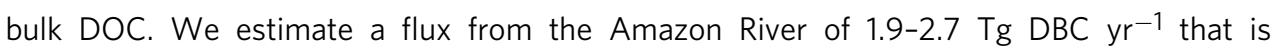
composed of predominately young $\mathrm{DBC}$, suggesting that loss processes of modern $\mathrm{DBC}$ are important.

\footnotetext{
${ }^{1}$ Department of Geography, University of Zurich, Winterthurerstrasse 190, 8057 Zürich, Switzerland. ${ }^{2}$ Research Group for Marine Geochemistry, Institute for Chemistry and Biology of the Marine Environment (ICBM), University of Oldenburg, D-26129 Oldenburg, Germany. ${ }^{3}$ Marine Sciences Laboratory, Pacific Northwest National Laboratory, 1529 West Sequim Bay Road, Sequim, WA 98382, USA. ${ }^{4}$ School of Oceanography, University of Washington, Box 355351, Seattle, WA 98195, USA. ${ }^{5}$ Geological Institute, Department of Earth Sciences, ETH Zürich, Sonneggstrasse 5, 8092 Zürich, Switzerland. ${ }^{6}$ Laboratory of Ion Beam Physics, ETH Zürich, Otto-Stern-Weg 5, 8093 Zürich, Switzerland. ${ }^{7}$ Tyndall Centre for Climate Change Research, School of Environmental Sciences, University of East Anglia, Norwich NR4 7TJ, UK. ${ }^{8}$ Helmholtz Institute for Functional Marine Biodiversity at the University of Oldenburg (HIFMB), Ammerländer Heerstraße 231, 26129 Oldenburg, Germany. Correspondence and requests for materials should be addressed to A.I.C. (email: Alysha.coppola@geo.uzh.ch)
} 
B iomass burning and fossil fuel combustion release vast amounts of carbon into the atmosphere, causing large changes in Earth's climate ${ }^{1,2}$. Up to $27 \%$ and $0.2 \%$ of carbon from the incomplete combustion of biomass and fossil fuel, respectively, is retained as condensed forms of carbon (called pyrogenic or black carbon, BC, ranging from charcoal to soot) rather than emitted as greenhouse gases ${ }^{3}$. In addition to impacting radiative budgets, $\mathrm{BC}$ also influences biogeochemical processes because it is a very large and refractory component of the global carbon cycle ${ }^{4,5}$. For example, particulate BC (PBC) acts as a biospheric carbon $\operatorname{sink}^{3,6,7}$ by removing carbon from faster atmosphere-biosphere processes and sequestering this carbon to sedimentary reservoirs.

To predict how the carbon cycle may respond to climate change, we need to determine the origin, dynamics, and fate of this abundant and slowly cycling component in the carbon cycle. A large portion of $\mathrm{BC}$ is exported to the ocean by rivers as dissolved BC (DBC) $\left(27 \mathrm{Tg}_{\text {year }}{ }^{-1}\right)^{8}$, thereby connecting marine and terrestrial carbon cycles ${ }^{8,9}$. Atmospheric deposition is another major pathway in which $\mathrm{BC}$ reaches rivers (after mobilization from the landscape $)^{10}$ and also the ocean $\left(1.8-10 \mathrm{Tg} \text { year }^{-1}\right)^{11,12}$. Uncertainties in regional and global-scale BC budgets persist due to poor constraints on its fluvial dynamics and export. Current estimates suggest that the input by rivers alone to the ocean is sufficient to sustain the turnover of the entire oceanic BC pool in just $500{ }^{14} \mathrm{C}$ years given current known losses of $\mathrm{BC}$, yet measured ${ }^{14} \mathrm{C}$ ages of $\mathrm{BC}$ in the deep sea are 40 times greater $(>20,000$ ${ }^{14} \mathrm{C}$ years $)^{13-15}$. Our understanding of the role of $\mathrm{BC}$ in the regional and global-scale carbon cycle remains inadequate, due in large part to poor constraints on the processing, quality, and fate of DBC during river export to the ocean ${ }^{16}$.

Rivers are the primary link by which $\mathrm{BC}$ is transferred laterally from terrestrial pools to the oceans ${ }^{9,16}$. Currently, large gaps exist with respect to the processes, pathways, and timescales over which DBC is mobilized and transported from land to ocean ${ }^{16-19}$, leading to challenges in reconciling $\mathrm{BC}$ cycling on terrestrial landscapes (modern to 1000 years mean residence time) with its longevity in the deep oceans $\left(>20,000{ }^{14} \mathrm{C} \text { years }\right)^{14}$. The annual export of $\mathrm{DBC}$ is large (27 Tg/year), and represents a significant fraction (i.e., $\sim 10 \%$ ) of overall riverine dissolved organic carbon $(\mathrm{DOC})^{9}$. Surprisingly, riverine DOC and DBC concentrations appear to be coupled $9,17,18,20$ regardless of fire history in upstream catchments, and despite substantial lags between the production of charcoal BC and river DBC export ${ }^{21-23}$. For example, in the Paraíba do Sul River in Brazil, DBC is continuously mobilized irrespective of fire history, with annual export far exceeding contemporary BC production rates ${ }^{21}$. DBC is partially removed during mobilization from soils during the wet season ${ }^{22}$, implying storage of $\mathrm{BC}$ in intermediate reservoirs (such as soils) prior to release to the river network ${ }^{24}$. BC has residence times of centuries in soils ${ }^{25}$, while turnover times are on the order of millennia in the deep ocean ${ }^{13,14}$. These contrasting turnover times suggest that aging may occur along the land-river-ocean transport continuum. Alternatively, more reactive $\mathrm{DBC}$ pools could be selectively removed during storage and transport, resulting in an apparent increase in age of residual DBC. For example, low-temperature combustion products derived from modern wildfires are re-mineralized during transport in Arctic river systems on the timescale of $20-40$ days $^{26}$. However, analyzing the DBC radiocarbon composition $\left(\Delta^{14} \mathrm{C}\right)$ is needed to understand how these remineralization processes influence the age distribution and recalcitrance as DBC is transported from river to ocean reservoirs. On a global scale, $\mathrm{PBC}$ in rivers is refractory, but $\Delta^{14} \mathrm{C}$ measurements on different river systems suggest that the extent of storage within river catchments varies widely for PBC pools ${ }^{8}$. Information on the radiocarbon composition of riverine $\mathrm{DBC}$ is currently limited to a single study ${ }^{17}$.

The Amazon River accounts for one-fifth of global freshwater discharge to the ocean ${ }^{27}$, and is the largest single source of terrestrial organic matter to the ocean (with an average annual DOC export of $22-27 \mathrm{Tg})^{28,29}$. Thus, the Amazon River is a crucial system in which to understand DBC cycling and transport and to develop constraints on global BC dynamics. The Amazon Basin transitions between pristine forest and urban influenced aerosol polluted plumes due to rapid developments in energy, agriculture expansion, and deforestation ${ }^{30}$. Here, we collected dissolved organic matter (DOM) and DBC samples for molecular characterization and radiocarbon analysis in four tributaries (Negro, Madeira, Trombetas, and Tapajós Rivers) and the Amazon River mainstem in November 2015 during one of driest seasons following a strong El Niño (Methods Sampling and Site Locations, Supplementary Fig. 1). This period represents the low flow of water during which the floodplain complexity and connectivity is limited, as we sampled only permanent waters ${ }^{31}$. Although DOC export is greatest during intervals of peak discharge ${ }^{32}$, we selected this low flow period for analysis to reduce complexity in watershed DBC sources associated with floodplain dynamics. We measured the concentration and radiocarbon content $\left(\Delta^{14} \mathrm{C}\right.$ values) of DBC in solid phase-extracted (SPE) DOC using molecular proxies (benzene polycarboxylic acids, BPCAs) ${ }^{33}$ released through chemical oxidation from the polycyclic condensed aromatic structure of BC. We pair these quantitative measurements of DBC molecular markers with DOM molecular characterization using ultrahigh-resolution mass spectrometry (Fourier transform ion cyclotron resonance mass spectrometry; FT-ICR-MS $)^{34-36}$. DBC $\Delta^{14} \mathrm{C}$ measurements reveal that DBC within the Amazon River and its tributaries generally are modern in age, but considerable spatial heterogeneity exists. Notably, there are very low DBC $\Delta^{14} \mathrm{C}$ values at Trombetas-Oriximina, Amazonas-Santarem, Óbidos, and near Manaus. However, further downstream, the Amazon River exports modern DBC to the ocean.

\section{Results}

Spatial decoupling of DBC and DOC concentrations and trends. We observe incongruent dynamics of DBC and DOC concentrations. DOC concentrations along the mainstem range from $3.3 \pm 0.3 \mathrm{mg} \mathrm{L}^{-1}$ upstream to $2.5 \pm 0.2 \mathrm{mg} \mathrm{L}^{-1}$ downstream at Manacapuru (station 11) to Almeirim (station 1), respectively (Supplementary Fig. 2). Tributary concentrations range from 1.6 \pm 0.5 to $6.8 \pm 0.5 \mathrm{mg} \mathrm{L}^{-1}$ in the Tapajós River (station 2) to Negro River (station 12), respectively. The DOC flux along the Amazon River mainstem increases from $183 \mathrm{~kg} \mathrm{C} \mathrm{s}^{-1}$ at Manacapuru (station 11) to $229 \mathrm{~kg} \mathrm{C} \mathrm{s}^{-1}$ at Almeirim (station 1) (Supplementary Table 1, Supplementary Fig. 2). With the exception of an Amazon River mainstem sample near Parintins that has a significantly higher DBC concentration $\left(802 \pm 160 \mu \mathrm{g} \mathrm{L}^{-1}\right.$, station 6), DBC concentrations range from $103 \pm 21 \mu^{-1} \mathrm{~L}^{-1}$ in the Tapajós River tributary (station 2), to $181 \pm 36 \mu \mathrm{g} \mathrm{L}^{-1}$ at Almeirim (station 1) to $495 \pm 90 \mu \mathrm{g} \mathrm{L}^{-1}$ at Santarém (station 3) (Fig. 1). The weighted average DBC concentration is $264 \pm 20 \mu \mathrm{g} \mathrm{L}^{-1}(22 \pm 4 \mu \mathrm{M})$ along the mainstem $(n=8)$. There is also a general increase in DBC fluxes downstream from Manacapuru (station 11) to Almeirim (station 1) from 13.3 to $16.6 \mathrm{~kg} \mathrm{~s}^{-1}$, respectively (Supplementary Table 2, Supplementary Fig. 2). This lack of covariation between DBC and DOC concentrations along the river $(p=0.59)$ during low flow contrasts with observations from other rivers globally $9,20,37$. Although documented in other river catchments ${ }^{35,38}$, this decoupling between DBC and DOC concentrations may be a consequence of the extreme drought conditions throughout the 


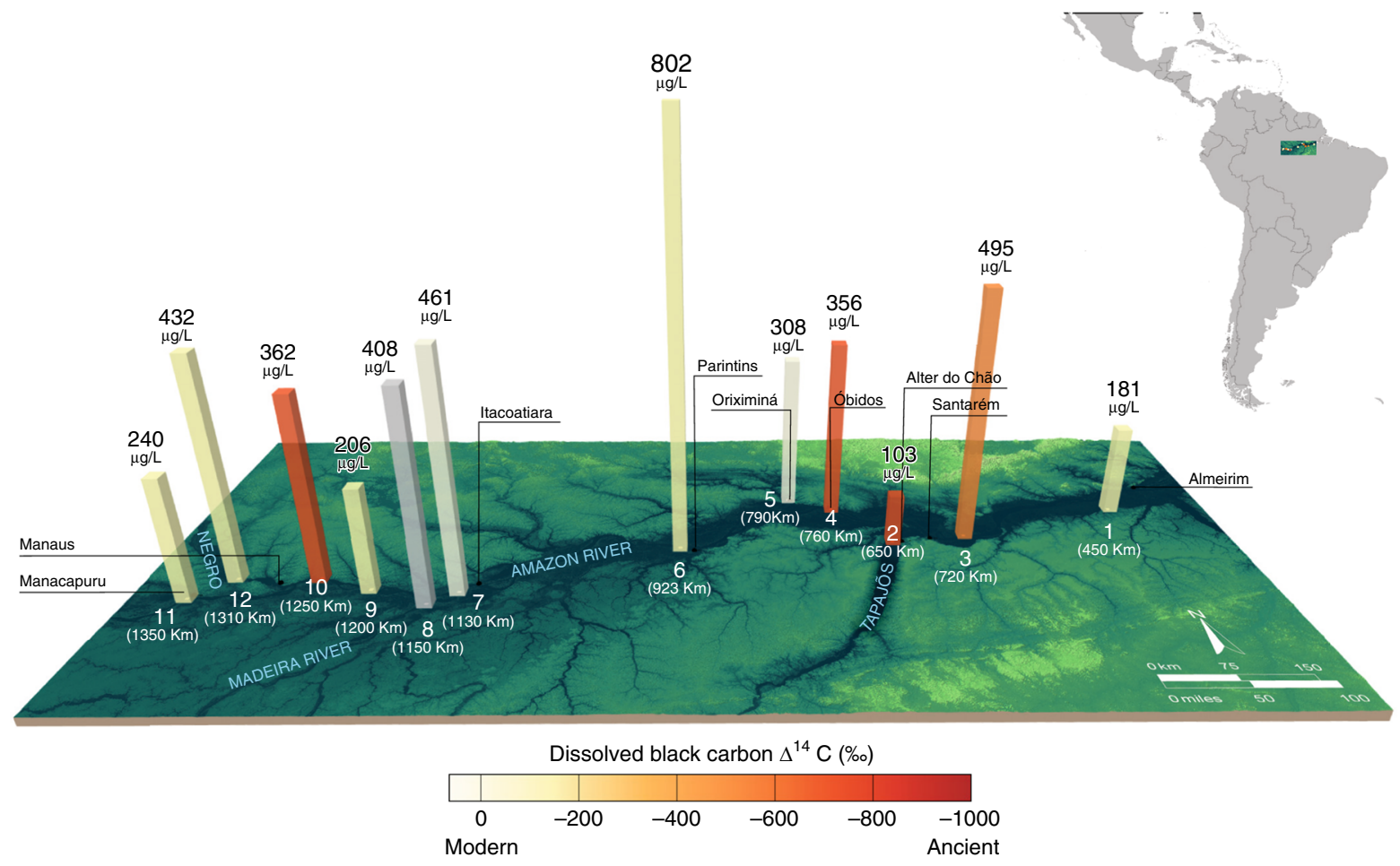

Fig. 1 Dissolved black carbon concentration and radiocarbon values. Sample locations plotted as distance to the river mouth (in $\mathrm{km}$, in white text) with the river (in blue text) and nearest city (black text). Dissolved black carbon (DBC) concentrations are shown by the height of the columns in $\mu g \mathrm{DBC} \mathrm{L}^{-1}$. The shades of yellow to red of columns represents modern to ancient $\mathrm{DBC} \Delta^{14} \mathrm{C}$ values. Station locations (in white) are labeled 1-12 according to Supplementary Fig. 1. The gray column at station 8 indicates no DBC $\Delta^{14} \mathrm{C}$ data. Error bars (s.d) are given in Supplementary Table 1

Amazon basin in $2015^{39,40}$, which may have affected the dynamics of DOC in this catchment. The lack of correlation between DBC and DOC concentrations in tropical rivers $(p<0.6023)$ may result from the divergent effects of soil properties, temperature, rainfall, and aerosol deposition on bulk DOC and its DBC mobilization from catchments ${ }^{38,41}$.

Isotopic heterogeneity of DBC. SPE-DOC shows $\triangle^{14} \mathrm{C}$ values $(-10 \pm 24 \%$ o to $+55 \pm 30 \%$ o $)$ consistent with modern biospheric inputs at all stations (Supplementary Fig. 3). The latter coupled with corresponding stable carbon isotopic compositions $\left(\delta^{13} \mathrm{C}\right.$ values $-28.5 \pm 0.8 \%$ to $-31.5 \pm 0.1 \%$ ) (Supplementary Table 1) suggests contemporary lowland $\mathrm{C} 3$ plants as the dominant source of DOC ${ }^{42,43}$. Also, DBC $\Delta^{14} \mathrm{C}$ values are mostly consistent with a modern river source ${ }^{13}$ (weighted average, $-46 \pm 15 \%, n=7$ ). However, DBC $\Delta^{14} \mathrm{C}$ values are markedly lower at four sites (station 10, Amazonas-20 km downstream of Manaus $-720 \pm$ $8 \%$; station 4, Amazonas-Óbidos, $-658 \pm 7 \%$; station 3, Amazonas-Santarém $-431 \pm 14 \%$; station 2, Tapajós-Alter do Chão, $-771 \pm 16 \%$ o (Fig. 1, Supplementary Table 2$)$ ). The very low DBC $\Delta^{14} \mathrm{C}$ values suggest that DBC is not stored in shortterm intermediate reservoirs prior to export. The DBC $\Delta^{14} \mathrm{C}$ values are not correlated to DOC flux $(p=0.260)$, discharge ( $p=$ 0.36 ), or other catchment-specific parameters, such as land cover ( $p=0.385$ for wetlands, $p=0.094$ for croplands, $p=0.516$ for natural vegetation) burned $(p=0.283)$ or urbanized area $(p=$ 0.985 ) (Supplementary Fig. 4, Supplementary Table 3). The low DBC $\Delta^{14} C$ values are also not reflected in abundances of DBC molecular markers (Supplementary Fig. 5). There are several potential explanations for the presence of these four strongly ${ }^{14} \mathrm{C}$ depleted riverine DBC values. For example, there is an anthropogenic aerosol plume $8-70 \mathrm{~km}$ downwind of Manaus from regional urbanization ${ }^{44}$ that may contribute to the low $\Delta^{14} \mathrm{C} \mathrm{DBC}$ values we observe at station $10(20 \mathrm{~km} \text { downwind })^{45}$. A second possible explanation for low DBC $\Delta^{14} \mathrm{C}$ values in mainstem sites just downstream of tributaries (e.g., Santarém) is that the collected water represented an impartial mixture of tributary and mainstem water considering that tributaries in the Amazon have been shown to be poorly mixed up to $100 \mathrm{~km}$ downstream of their confluence ${ }^{46}$. Additionally, although past measurements show that suspended POC in the lowland rivers studied here have modern radiocarbon signatures similar to $\mathrm{DOC}^{43}, \mathrm{PBC}$ in the Amazon River has a $\Delta^{14} \mathrm{C}$ value of $-386 \pm 43 \% 0\left(3900 \pm 770{ }^{14} \mathrm{C}\right.$ years $)^{8}$. This suggests that the old DBC values we observe here may have some contribution derived from sedimentary material desorbed into the dissolved phase. Overall, the sharp isotopic variability within the $\mathrm{DBC}$ brings up more questions than answers. However, in absence of further data we cannot reach a conclusion (see Supplementary Discussion for further information). Future field, laboratory and modeling studies to map urban and biomass burning emissions at different locations in the Amazon ${ }^{47}$ paired directly with $\Delta^{14} \mathrm{C}$ aerosol $\mathrm{BC}$, river $\mathrm{PBC}$, sediments and molecular composition directly need to be conducted to fully determine the primary driver of the observed low DBC $\Delta^{14} \mathrm{C}$ values at these four sites to test these open hypothesizes.

Compositional variability within DBC. Of the $\sim 12,000$ molecular formulae detected in SPE-DOM using FT-ICR-MS, we approximate $\sim 10 \%$ (1272 molecular formulae) contain a polycyclic aromatic (PCA) signature (aromaticity index, $\mathrm{AI}_{\text {mod }} \geq 0.67$, $\mathrm{C} \geq 15$ ), consistent with DBC-like sources. These PCA molecular formulae are strongly correlated to the DOM-normalized concentrations of B6CA marker compounds ( $p \leq 0.001, r=0.88)$, 

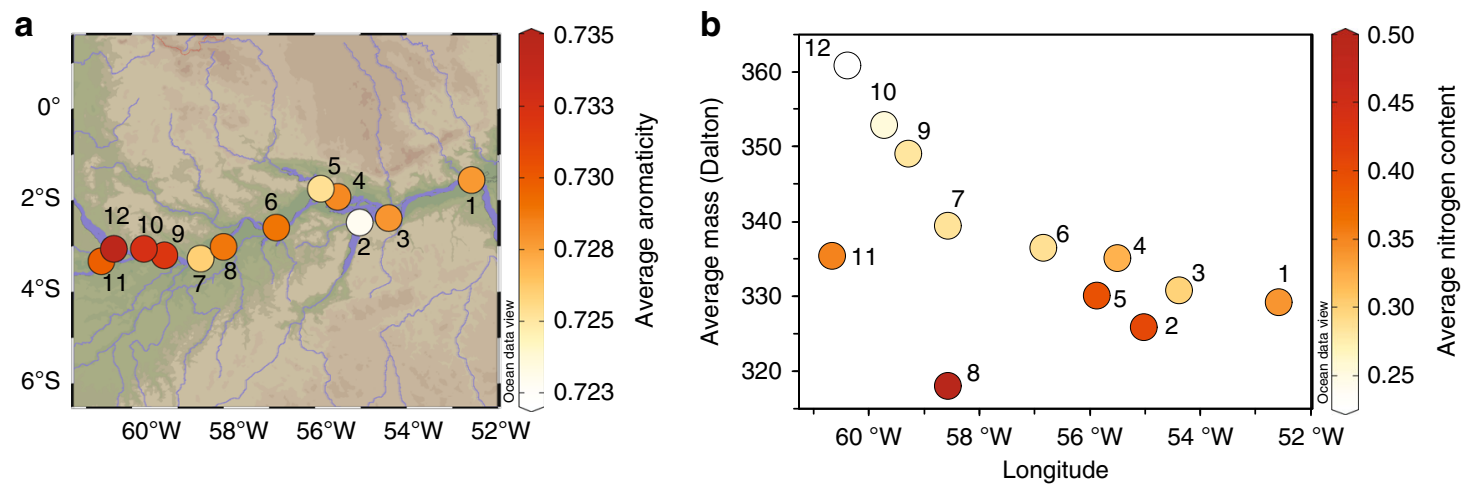

Fig. 2 Polycyclic aromaticity and nitrogen content along the Amazon River. Molecular parameters of the 1272 detected polycyclic aromatic molecular formulae with aromaticity index $\geq 0.67$ as analyzed by Fourier transform ion cyclotron resonance mass spectrometry (FT-ICR-MS). By definition, polycyclic aromatics include thermogenic DBC molecular formulae. Numbers on the plot correspond to station locations in Supplementary Table 1. a Plot of the intensity weighted-average aromaticity per samples of polycyclic aromatic molecular formulae along the sampling transect, given by shades of red. The aromaticity decreased relatively downstream. b The intensity weighted-average molecular mass (in Daltons) of polycyclic aromatic molecular formulae over the sampling transect with number of polycyclic aromatic molecular formulae with color-coded intensity weighted-average of nitrogen content of the polycyclic aromatic molecular formulae along longitude. The number of polycyclic aromatic molecular formulae decreased downstream while the relative content of nitrogen per polycyclic aromatic molecular formula increased

indicating a common origin from highly condensed compounds of pyrogenic and combustion sources. The weighted-average aromaticity of PCA molecular formulae decreases downstream (Fig. 2) concomitant with a decrease in more condensed BC structures given by higher B6CA marker concentrations and B6CA/B5CA ratios (Supplementary Fig. 3, Supplementary Note 1), suggesting downstream loss of more condensed BC structures by photooxidation ${ }^{48-50}$. The shift to smaller and less polycondensed DBC structures (Supplementary Fig. 6) may be a consequence of preferential removal of polycondensed PCA compounds due to photo-degradation ${ }^{48}$ or sorptive interaction processes along the river continuum.

The relative increase of the nitrogen content in the polycondensed aromatic molecular formulae (referred to as dissolved black nitrogen), may also suggest increased fossil fuel inputs ${ }^{51}$. The contribution of aerosol fossil fuel inputs that likely caused drastic changes in $\mathrm{DBC} \Delta^{14} \mathrm{C}$ values along the river continuum is not reflected in the DOM molecular formulae. This suggests either similarities in PCA molecular formulae composition despite contrasting isotopic values and sources (i.e. fossil fuel vs. soils) or that the DBC changes are not detectable in bulk DOM molecular formulae ${ }^{19}$. The latter may be a consequence of restrictions in the analytical window of FT-ICR-MS due to differences in ionization efficiency of different DBC compounds derived from soot and charcoal inputs ${ }^{19}$.

\section{Discussion}

Based on the average annual Amazon River DOC export $(22-27 \mathrm{Tg})$ and a range of $\mathrm{DBC} / \mathrm{DOC} \%$ values at low and high flow $(7.2 \pm 0.5 \%$, at Almeirim, site $1 ; \mathrm{DBC} / \mathrm{DOC} \%$ of $9.9 \pm 1.0 \%$ at Macapa ${ }^{52}$, respectively), we estimate an annual flux of DBC of 1.9-2.7 Tg from the Amazon River basin to the Atlantic Ocean (Methods, Supplementary Table 2). Based on the current estimate of $27 \mathrm{Tg}$ year $^{-1}$ for global riverine DBC export ${ }^{9}$, this corresponds to $7-10 \%$ of the global fluvial DBC flux to the oceans. This represents a lower estimate of DBC flux, based on a dry season sampling period from a station $450 \mathrm{~km}$ (Amazonas-Almeirim) upstream from the mouth of the Amazon, as compared to $\sim 1175 \mathrm{~km}$ upstream peak discharge sampling location used in the global study ${ }^{9}$ (as a composite sample of 25\% Rio Negro and $75 \%$ Rio Solimões, at $\left.3.13^{\circ} \mathrm{S}, 59.92^{\circ} \mathrm{W}, 400 \mu \mathrm{g} \mathrm{L}-1,9.5 \% \mathrm{DBC} / \mathrm{DOC} \%\right)$.
We also report significantly lower DOC concentrations $\left(2.5 \pm 0.2 \mathrm{mg} \mathrm{L}^{-1}\right.$ compared to $\left.4.2 \pm 0.9 \mathrm{mg} \mathrm{L}^{-1}\right)$ than those annual measurements given by Ward et al. ${ }^{32}$. Our estimate to the marine DBC pool does not include any fossil fuel aerosol inputs, given that they apparently have only local, ephemeral influence on riverine DBC as fossil fuel signals are removed downstream. Thus, we used the modern DBC values at Almeirim to estimate mass balances between river and the marine DBC pools.

The predominately modern DBC $\Delta^{14} \mathrm{C}$ signature $(-46 \pm 15 \%$ ) suggests that $\mathrm{DBC}$ is not stored in short-term intermediate reservoirs within the Amazon River, at least during low-flow conditions. Using our measurements as the riverine endmember, a mass balance calculation assuming a background marine DBC pool $(-945 \pm 6 \%$ o $)$ and a freshwater river influence of $20 \%{ }^{13}$, yields a $\Delta^{14} \mathrm{C}$ value for Amazon plume marine $\mathrm{DBC}$ of $-765 \pm$ $35 \%$, which agrees within error of the measured $\mathrm{BC}$ value $\left(-727 \pm 44 \%\right.$; $10,400 \pm 1300{ }^{14} \mathrm{C}$ years $)$ in ultra-filtered $\mathrm{DOC}^{13}$. This suggests that modern $\mathrm{DBC}$ is exported from the Amazon River, regardless of hydrological state, where it contributes to oceanic DBC.

The marine DBC pool is older and smaller than expected given the riverine $\mathrm{DBC}$ signature and input rates $\left(23,000^{14} \mathrm{C}\right.$ years and only $\left.12-14 \mathrm{Tg}^{14,53}\right)$, suggesting that $\mathrm{DBC}$ loss by processes, such as UV oxidation and sedimentation, must be important ${ }^{48}$. For example, we would expect a larger concentration of DBC in the Amazon River plume $(3.3 \pm 0.8 \mu \mathrm{M})$ than observed $(0.3 \mu \mathrm{M}, \mathrm{BC}$ in ultra-filtered $\left.\mathrm{DOC}^{13}\right)$. Thus, along with DOM, a portion of DBC may be decomposed along the river-ocean interface by photochemical degradation both at the mouth-plume interface, and where the clearwater tributaries $\mathrm{mix}^{54}$. Yet, not all DBC is removed at this interface because a smaller signal of recalcitrant DOM, including DBC, persists to the river-mouth interface at the Atlantic Ocean ${ }^{52,54}$. Medeiros et al. (2015) found that dilution was the primary factor influencing DOM variability in the plume ( $\sim 60 \%$ of total variability), while biodegradation, photo-oxidation, and phytoplankton production all played a smaller, but relevant role $(\sim 5-8 \% \text { of variability each })^{52}$.

There are at least two marine DBC pools-younger pool cycling on centennial timescales and a stable pool with residence times $>10^{5}$ year timescales ${ }^{14,17}$. Another modern and semi-labile DBC pool from rivers may contain recent biosphere-derived BC that has not accumulated on land due to short continental 
residence times, as observed here. Our study suggests that $\mathrm{DBC}$ is predominately of modern origin in the Amazon River, but some river $\mathrm{DBC}$ does survive to accumulate in the ocean. $\mathrm{DBC}$ dynamics appear to be decoupled from those of DOC in this study. Labile DBC may be decomposed along the river-ocean continuum, particularly in clearwater tributaries and beyond the plume where photochemical degradation may occur, while contributions from atmospheric (aerosol) BC deposition may be locally important, but rapidly removed or diluted during downstream transport. Future work is needed to understand the underlying causes of this de-coupling, seasonal and interannual variability in isotopic values and fossil fuel aerosol DBC and $\mathrm{PBC}$ contributions in the Amazon during high and low flows.

\section{Methods}

Sampling and site locations. DBC samples were collected along the Amazon River in November 2015, during the dry season. The 12 sites were accessible by boat. We sampled in the dry season because the flood plain extents are the lowest in November and December ${ }^{55}$. During the dry season, the hydrological connectivity of the Amazon decreases, as overbank flow paths, and lakes serving reservoirs (for flood waters, rainfall, and saturated water table seepage) decrease.

Surface water (at $1 \mathrm{~m}$ ) samples were collected using deployed $2 \mathrm{~L}$ Niskin sampling cylinders from a small ship. The Niskin was deployed and flushed with river water before samples were collected. Samples were collected in the middle of the river when possible. Samples were also collected away from boat traffic, and all sampling was conducted in a covered area on the boat. First, all water from the five Niskin deployments were combined in acid-washed container, rinsed with river water before being filled. Samples were filtered using combusted GF/F filters (Whatman, nominal pore size $0.7 \mu \mathrm{m}$ ) to remove POC. The filtrate river water was subsampled into acid cleaned, pre-combusted amber glass bottles $(100 \mathrm{~mL})$, and acidified for later DOC concentration and $\Delta^{14} \mathrm{C}$ analysis. Measurements were taken from distinct samples. To obtain enough DOC for DBC analysis, DOC (ranging from 8.8-10 L) was loaded onto solid phase extraction (SPE) cartridges. Briefly, DOC was concentrated according to Dittmar et al. ${ }^{56}$, as DOC was acidified to $\mathrm{pH}$ 2 (around $20 \mathrm{~mL}$ high purity $\mathrm{HCl}$ ) and samples were concentrated via SPE on PPL resin (5 g, Agilent \#12256087) immediately after collection. $10 \mathrm{~L}$ of DOC (placed in two acid-cleaned plastic bottles) was loaded by gravity filtration onto a manifold consisting of four SPE cartridges. DOC was loaded onto a manifold of four SPE cartridges to generate four duplicates per site, stored at $-25^{\circ} \mathrm{C}$ and shipped back to the University of Zurich before elution. Salt was removed by rinsing all SPE cartridges with $0.01 \mathrm{~mol} \mathrm{~L}^{-1} \mathrm{HCl}$. The PPL cartridges were dried under a gentle stream of $\mathrm{N}_{2}$, DOC was eluted using $30 \mathrm{~mL}$ of high purity methanol. The SPE-DOC recovery (compared to DOC concentrations) was $63 \pm 5 \%$.

The molecular DOM composition was analyzed from SPE-DOC samples via 15T FT-ICR-MS (solariX XR, Bruker Daltonics) with electrospray ionization (ESI) in negative mode as described in ref. ${ }^{57}$. Briefly, methanol extracts were diluted 1:1 $(\mathrm{v} / \mathrm{v})$ in ultrapure water to $5 \mu \mathrm{g} \mathrm{C} \mathrm{L}^{-1}$. Mass spectra were collected over 200 scans, with an ion accumulation time of $0.15 \mathrm{~s}$, in a range of $92-2000 \mathrm{~m} / \mathrm{z}$. Molecular formulae were calculated for masses with relative intensities above the method detection limit ${ }^{58}$ allowing $\mathrm{C}_{1-130} \mathrm{H}_{1-200} \mathrm{O}_{1-50} \mathrm{~N}_{0-4} \mathrm{~S}_{0-2} \mathrm{P}_{0-1}$. Intensity-weighted averages of aromaticity (modified aromaticity index, $\mathrm{AI}_{\bmod }{ }^{59,60}$, number of atoms per molecular formula (carbon, $\mathrm{C}$, hydrogen, $\mathrm{H}$, oxygen, $\mathrm{O}$, nitrogen, $\mathrm{N}$, sulfur, $\mathrm{S}$, and phosphorus, $\mathrm{P}$ ), and molar ratios (hydrogen-to-carbon, $\mathrm{H} / \mathrm{C}$ and oxygen-tocarbon, $\mathrm{O} / \mathrm{C}$ ) were calculated for each sample by considering the peak intensity of each assigned molecular formula as described in ref. ${ }^{57}$. Principal coordinate analysis (PCoA) was performed on a Bray-Curtis dissimilarity matrix of the normalized peak intensities of PCA molecular formulae $\left(\mathrm{AI}_{\bmod } \geq 0.67, \mathrm{C} \geq 15\right)$ post-hoc fitted with environmental data and molecular parameters using the envfit function of the vegan package ${ }^{61}$ within the $\mathrm{R}$ statistical platform ${ }^{62}$.

Dissolved black carbon concentrations. DBC was extracted from the SPE-DOM methanol extracts using the BPCAbenzene polycarboxylic acid (BPCA) method $^{33,63}$. Briefly, SPE-DOM extracts were dried and lyophilized for $24 \mathrm{~h}$. Concentrated nitric acid was added to the sample in a quartz pressure digestion chamber at $170{ }^{\circ} \mathrm{C}$ for $8 \mathrm{~h}$ to produce BPCAs. After digestion, the solution was filtered, lyophilized, and re-dissolved in methanol. BPCAs were separated and collected on a preparative liquid chromatography using an Agilent 1290 infinity HPLC system equipped with a $2.7 \mu \mathrm{m}$ Agilent Poroshell $120 \mathrm{C}-18$ column. A reverse phase analytical C-18 column (Agilent, $2.7 \mu \mathrm{m}$ ) was used with two mobile phases of pH 2 Milli-Q $\left(1.7 \% \mathrm{H}_{3} \mathrm{PO}_{4}\right)$ and acetonitrile $\left(>99.98 \%\right.$ Scharlau, $\mathrm{F}^{14} \mathrm{C}<$ 0.004). Quantification of BPCAs were made from seven-point calibration curves (2-200 ng $\left.\mu \mathrm{L}^{-1}\right)$ using commercially available BPCA standards including pentacarboxylic acid (Aldrich S437107) and hexacarboxylic acid (Aldrich M2705) to quantify the BPCAs measured from peak areas obtained from the diode array detector (60 mm path length) chromatographs. A BC recovery factor of $23.2 \pm 0.4 \%$ was used for the conversation of BPCAs to estimate $\mathrm{BC}^{64,65}$ for comparison with published values.
Isotopic analysis. For DBC $\Delta^{14} \mathrm{C}$ analysis, B5CA and B6CA marker compounds were collected in the fraction collector of the HPLC, according to Wiedemeier et al. ${ }^{33}$. The B2CA marker compounds were not collected, because they may also be derived from aromatic compounds of non-combusted origin (e.g. lignin). Dead $\left(\mathrm{F}^{14} \mathrm{C}=0.003 \pm 0.001\right)$ and modern $\left(\mathrm{F}^{14} \mathrm{C}=1.149 \pm 0.004\right)$ wood char black carbon standards during the entire BPCA procedure were used to evaluate the extraneous, or non-sample blank carbon added to samples during chemical processing ${ }^{66}$ (Supplementary Fig. 8). BPCAs in the vials were dried under a gentle stream of ultra-high purity nitrogen on a heating plate $\left(70{ }^{\circ} \mathrm{C}\right)$ for $3 \mathrm{~h}$, and stored at $-25^{\circ} \mathrm{C}$ until wetoxidation to $\mathrm{CO}_{2}$ gas for isotopic analyses ${ }^{67,68}$.

For DOC $\Delta^{14} \mathrm{C}$ analysis, and DOC concentration measurements we used a wet-chemical oxidation following Lang et al. ${ }^{67}$ and Wiedemeier et al. ${ }^{33}$. Briefly, $8 \mathrm{~mL}$ of acidified DOC ( $\mathrm{pH} 2, \mathrm{HCl})$ was transferred into pre-combusted borosilicate glass Exetainer (septa sealed $4.5-\mathrm{mL}$ exetainers vials from Labco Limited, UK) vials, frozen and freeze dried overnight (with pre-combusted aluminum covers). Samples were re-dissolved in Milli-Q water to a final volume of $4 \mathrm{~mL}$. Milli-Q blanks, modern and dead standards (sucrose and phthalic acid) were used to evaluate the extraneous carbon added during the wet chemical oxidation procedure.

BPCAs and DOC were then converted to $\mathrm{CO}_{2}$ using the wet oxidation procedure for $\Delta{ }^{14} \mathrm{C}$ measurement using a gas ion source $\mathrm{AMS}^{33,67,68}$. Briefly, $30 \mu \mathrm{g}$ C BPCA samples, $1 \mathrm{~mL}$ of purified sodium persulfate and $3 \mathrm{~mL}$ of Milli-Q water (for a total volume of $4 \mathrm{~mL}$ ) were transferred to gas-tight borosilicate Exetainer vials. All samples were purged with ultra-high purity helium $(100 \mathrm{~mL}$ min ${ }^{-1}, 8 \mathrm{~min}$ to remove atmospheric $\mathrm{CO}_{2}$ ), and oxidized to $\mathrm{CO}_{2}$ in a heating block $\left(95^{\circ} \mathrm{C}, 1 \mathrm{~h}\right)$. Radiocarbon measurements of DBC and DOC were made on the Mini Carbon Dating System (MICADAS) Accelerator Mass Spectrometer coupled to a carbonate system modified with a needle to sparge sample solutions at the ETH Zurich Ion Beam Laboratory. DBC samples were corrected for extraneous carbon according to Hanke et al. ${ }^{68}$ (Supplementary Fig. 8,

Supplementary Table 2) and all samples were corrected using phthalic acid and sucrose standards. Radiocarbon is reported in $\mathrm{F}^{14} \mathrm{C}$ then converted to $\Delta^{14} \mathrm{C}(\%)$ using the year of sampling. For DOC concentration measurements, the $\mathrm{CO}_{2}$ gas measured by the AMS was normalized to the volume of DOC used $(8 \mathrm{~mL})$. DOC concentration measurements were better than $0.03 \%$ based on standards. Radiocarbon measurements were corrected for isotopic fractionation via ${ }^{13} \mathrm{C} /{ }^{12} \mathrm{C}$ isotopic ratios. ${ }^{14} \mathrm{C}$ data are reported as $\Delta^{14} \mathrm{C}$ values (\%o).

For $\delta^{13} \mathrm{C}$ of SPE-DOC, we also used the wet-oxidation procedure to prepare samples, following Lang et al. ${ }^{69}$ at ETH Zurich. The SPE-DOC stable organic isotopic composition $\left(\delta^{13} \mathrm{C}, \% \mathrm{VPDB}\right)$ was measured on the headspace $\mathrm{CO}_{2}$ with a Gas Bench II on-line gas preparation and introduction system (Thermo Fisher Scientific, Bremen, Germany). Samples were prepared 1 day before processing for $\delta^{13} \mathrm{C}$. The Gas Bench II is equipped with a CTC autosampler (CTC Analystics AG, Zwingen, Switzerland) and coupled to a ConFlo IV interface and a Delta V Plus mass spectrometer (both Thermo Fisher Scientific). For each sample, three reference gas peaks are measured and the sample gas is introduced four times into the mass spectrometer. The blank was $0.2 \mu \mathrm{g}$ C. Corresponding $\delta^{13} \mathrm{C}$ values were determined to an accuracy of $\pm 0.1 \%$ based on phthalic acid and sucrose standards. BPCA $\delta^{13} \mathrm{C}$ could not be measured because sample sizes were too small.

Gauge measurements and mass balance hydrological approach. We relied on a combination of gauge records, direct measurements during November 26-December 11, 2014 and mass balance approximations to estimate discharge in November 2015. Daily gauge data were taken from the network Agência Nacional de Águas (ANA), from the data portal Séries Históricas de Estações for Manacapurú and Óbidos (http://www.snirh.gov.br/hidroweb/publico/ medicoes_historicas_abas.jsf). Rio Madeira and Alter do Chão (Rio Tapajós) and Rio Negro were derived from upstream ANA stations. Almeirim was measured directly by ADCP by the TROCAS project ${ }^{70}$. The remaining stations were done by mass balance approximations (Supplementary Table 2). Calculated DOC loads $\left(\mathrm{Tg}_{\text {year }}{ }^{-1}\right)$ used these discharge measurements in Eq. (1), where DOC is the DOC concentration $\left(\mathrm{g} \mathrm{L}^{-1}\right)$ of $4.2 \pm 0.9 \mathrm{mg} \mathrm{L}^{-1}$ made at the river mouth ${ }^{32}$ multiplied by 1000 (in units of $\mathrm{L} \mathrm{m}^{-3}$ ), $60 \mathrm{~s}, 60 \mathrm{~min}, 24 \mathrm{~h}$, and 365 days, and the discharge $Q\left(\mathrm{~m}^{3} \mathrm{~s}^{-1}\right)$ of $203,000 \mathrm{~m}^{3} \mathrm{~s}^{-1}$ from Ward et al. ${ }^{32}$.

$$
(\text { DOC })(1000)(60 * 60 * 24 * 365) * Q
$$

$$
(\mathrm{DOC} * \mathrm{DBC} \%)(1000)(60 * 60 * 24 * 365) * Q
$$

We calculated DBC flux in $\mathrm{Tg}_{\text {year }}{ }^{-1}$ using Eq. (2), using the same DOC concentration $\left(\mathrm{g} \mathrm{L}^{-1}\right)$ and discharge $\left(\mathrm{m}^{3} \mathrm{~s}^{-1}\right)$ from Ward et al. ${ }^{32}$. To determine the flux to the ocean, we used the range of $\mathrm{DBC} \%$ during low flow conditions of $7.2 \pm 0.5 \%$ (this study, from Amazonas-Almeirim station 1) to high flow conditions of $9.9 \pm 1.0 \%$ (from 2010 at $\mathrm{Macapa}^{52}$ ). Although this is the first DBC Amazon flux estimate, this measurement includes DBC measurements during the dry season (2015) and wet seasons $(2010)^{52}$. For example, the DOC concentration at Amazonas-Almeirim $\left(2.5 \pm 0.3 \mathrm{mg} \mathrm{L}^{-1}\right)$ measured during this time period (2015) is much lower than the average concentration $\left(4.2 \pm 0.9 \mathrm{mg} \mathrm{L}^{-1}\right)$ made at the river mouth ${ }^{32}$. Future constrains on this first estimate can be made 
by sampling multiple cross channel locations, and at multiple depths, during all seasons across several years.

Catchment boundaries corresponding to each sample site were determined using a high-resolution $(\sim 500 \mathrm{~m})$ stream drainage direction map for the Amazon River basin ${ }^{71}$. Supplementary Fig. 1c, d was created with ArcMap 10.6, relief shade from Natural Earth dataset (http://www.naturalearthdata.com), catchments derived from CAMREX (Carbon in the Amazon River Experiment) dataset (https://daac. ornl.gov/LBA/guides/CD06_CAMREX.html) and runoff from GSCD ${ }^{72}$ (https:// water.jrc.ec.europa.eu/).

Land use, urbanization, and fire history. Land cover (from Modis 2012, at 15 arc minutes resolution https://modis.gsfc.nasa.gov/data/dataprod/mod12.php), urban areas (Global Rural-Urban Mapping Project GRUMP) ${ }^{73}$ and burned area (Global Fire Emissions Database, GFED4s) for each sample was integrated over the cell area $\left(\right.$ in $\mathrm{km}^{2}$ ) for the sample. We used an estimate of fire history from satellite observations from GFED4s (available http://www.globalfiredata.org/index.html for the past decades (1997-2015) $)^{74}$. The parameters were intergraded over the corresponding sample location's catchment area (Supplementary Fig. 4, Supplemen tary Table 3$)$ which was determined by using a high-resolution $(\sim 500 \mathrm{~m})$ stream drainage direction map for the Amazon River basin ${ }^{71}$ (Supplementary Fig. 1c). All panels in Supplementary Fig. 4 were created with ArcMap 10.6, with relief shade from Natural Earth dataset (http://www.naturalearthdata.com) and catchments derived from CAMREX (Carbon in the Amazon River Experiment) dataset (https://daac.ornl.gov/LBA/guides/CD06_CAMREX.html).

Atmospheric deposition of black carbon aerosols. Aerosol BC deposition was modeled for 2015 in South America using the UK Met Office Hadley Centre Global Environment Model version 2 earth system model (HadGEM2-ES ${ }^{10,75,76}$. Briefly, HadGEM2-ES represents the life cycle of aerosol species ${ }^{77}$, including from fossil fuel and biofuel emissions and from biomass burning. BC is modeled as an internally mixed component of organic carbon ${ }^{78}$. Processes such as transport, mixing and deposition are represented explicitly through physically based parameterizations that have been developed and constrained using observations. HadGEM2-ES was run with standard climate resolution $\left(1.875^{\circ} \times 1.25^{\circ}\right)$ in the period 2009-2016. Simulations were driven by a custom biomass burning aerosol emission dataset produced for South America as discussed by Jones et al. ${ }^{10}$. Briefly, published carbon stock consumption factors $\left(\mathrm{kg} \text { dry matter } \mathrm{km}^{-2}\right)^{79}$ and aerosol $\mathrm{BC}$ emission factors ( $\mathrm{g} \mathrm{BC} \mathrm{kg} \mathrm{dry} \mathrm{matter}{ }^{-1}$ ) ${ }^{80}$ were assigned to burned area cells according to land cover type in the MODIS MCD12Q1 dataset (resolution $500 \mathrm{~m}$ ) enhanced with information on ecoregion ${ }^{81}$ and agricultural land use ${ }^{82}$. Biomass burning aerosol emissions outside of South America were taken from the Global Fire Emission Dataset (GFED) version 3.183. Emissions of aerosol from fossil fuel sources followed the dataset employed in the Coupled Model Intercomparison Project phase 5 (CMIP5), based on the historical emissions ${ }^{84}$ with regional updates following the Representative Concentration Pathway (RCP) 8.585,86. The deposition rates from HadGEM2-ES were interpolated to a $0.05^{\circ}$ grid using an empirical Bayesian kriging operation performed in the ArcGIS Geostatistical Analyst toolbox. The approach and performance of the kriging process are reported by Jones et al..$^{10}$ and summarised in the supplementary material. Rates of biomass and fossil fuel-derived aerosol deposition $\left(\mathrm{kg} \mathrm{C} \mathrm{km}^{-2}\right.$ year $\left.^{-1}\right)$ were averaged within the upstream catchments of all sampling locations on the river network (Supplementary Fig. 4, Supplementary Table 3).

Deposition rates from HadGEM2-ES were transferred to higher-resolution grids using an empirical Bayesian kriging operation performed with the ArcGIS Geostatistical Analyst toolbox. The process was completed using a log-empirical transformation, Whittle de-trended semivariogram, and search radius of $4^{\circ}$. The normalized mean error of the predictions from the kriging operation, when compared to the data from the native HadGEM2-ES grid, was $0.7 \%$ for total fossil fuel $\mathrm{BC}$ aerosol and $1.7 \%$ for biomass burning $\mathrm{BC}$ aerosol deposition during 2009-2016. Predictions were mapped to a $0.05^{\circ}$ grid. The normalized root mean square error of the predictions from the kriging operation, when compared to the input data from the native HadGEM2-ES, was $5 \%$ for total fossil fuel $\mathrm{BC}$ aerosol and $15 \%$ for biomass burning $\mathrm{BC}$ aerosol deposition during 2009-2016.

Although the prevailing wind direction in Amazonia is from East to West, changes in wind direction provide an opportunity for aerosols emitted in southern Brazil to be transported northwards and deposited in the Amazon Basin ${ }^{41}$. This influences the distribution of $\mathrm{BC}$ aerosol deposition across central Brazil and leads to raised deposition rates in the south of the Amazon relative to northern regions that are further from the main population centers of the country. There may be an imprint of sources in southeast Brazil on the background deposition rates of northern export of $\mathrm{BC}$ from cities.

\section{Data availabilty}

The data set will be on the PANGAEA data (www.pangaea.de) repository following publication under the username alyshacoppola (connected to the ORCIDID https://orcid. org/0000-0002-9928-2786). In addition, all data are available from the corresponding author on request. Please contact Alysha Inez Coppola (Alysha.coppola@geo.uzh.ch, or at http://alyshainezcoppola.strikingly.com/) for correspondence and material requests.
Received: 22 March 2019 Accepted: 11 July 2019

Published online: 05 September 2019

\section{References}

1. Foster, G. L., Royer, D. L. \& Lunt, D. J. Future climate forcing potentially without precedent in the last 420 million years. Nat. Commun. 8, 14845 (2017).

2. Bowman, D. et al. Fire in the Earth system. Science 324, 481-484 (2009).

3. Santín, C. et al. Towards a global assessment of pyrogenic carbon from vegetation fires. Glob. Chang Biol. https://doi.org/10.1111/gcb.12985 (2015).

4. Santin, C., Doerr, S. H., Preston, C. M. \& Gonzalez-Rodriguez, G. Pyrogenic organic matter production from wildfires: a missing sink in the global carbon cycle. Glob. Change Biol. 21, 1621-1633 (2015).

5. Schmidt, M. W. I. \& Noack, A. G. Black carbon in soils and sediments: Analysis, distribution, implications, and current challenges. Glob. Biogeochem. Cycles 14, 777-793 (2000).

6. Landry, J.-S. \& Matthews, H. D. The global pyrogenic carbon cycle and its impact on the level of atmospheric $\mathrm{CO} 2$ over past and future centuries. Glob. Change Biol. 23, 3205-3218 (2017).

7. Jones, M. W., Santín, C., van der Werf, G. R. \& Doerr, S. H. Global fire emissions buffered by the production of pyrogenic carbon. Nat. Geosci., https://doi.org/10.1038/s41561-019-0403-x (2019).

8. Coppola, A. I. et al. Global-scale evidence for the refractory nature of riverine black carbon. Nat. Geosci. 11, 584-588 (2018).

9. Jaffe, R. et al. Global charcoal mobilization from soils via dissolution and riverine transport to the oceans. Science 340, 345-347 (2013).

10. Jones, M. W. et al. Do regional aerosols contribute to the riverine export of dissolved black carbon? J. Geophys. Res.-Biogeosci. 122, 2925-2938 (2017).

11. Bao, H., Niggemann, J., Luo, L., Dittmar, T. \& Kao, S.-J. Aerosols as a source of dissolved black carbon to the ocean. Nat. Commun. 8, 510 (2017).

12. Jurado, E., Dachs, J., Duarte, C. M. \& Simo, R. Atmospheric deposition of organic and black carbon to the global oceans. Atmos. Environ. 42, 7931-7939 (2008).

13. Ziolkowski, L. A. \& Druffel, E. R. M. Aged black carbon identified in marine dissolved organic carbon. Geophys. Res. Lett. 37, https://doi.org/10.1029/ 2010gl043963 (2010).

14. Coppola, A. I. \& Druffel, E. R. M. Cycling of black carbon in the ocean Geophys. Res. Lett. 43, 4477-4482 (2016).

15. Fatayer, S. et al. Direct visualization of individual aromatic compound structures in low molecular weight marine dissolved organic carbon. Geophys. Res. Lett. 45, 5590-5598 (2018).

16. Wagner, S., Jaffé, R. \& Stubbins, A. Dissolved black carbon in aquatic ecosystems. Limnol. Oceanogr. Lett. 3, 168-185 (2018).

17. Wang, X., Xu, C., Druffel, E. M., Xue, Y. \& Qi, Y. Two black carbon pools transported by the Changjiang and Huanghe Rivers in China. Glob. Biogeochem. Cycles n/a-n/a, https://doi.org/10.1002/2016GB005509 (2016).

18. Guerena, D. T. et al. Terrestrial pyrogenic carbon export to fluvial ecosystems Lessons learned from the White Nile watershed of East Africa. Glob. Biogeochem. Cycles 29, 1911-1928 (2015).

19. Wagner, S., Ding, Y. \& Jaffé, R. A new perspective on the apparent solubility of dissolved black carbon. Front. Earth Sci. 5, https://doi.org/10.3389/ feart.2017.00075 (2017).

20. Wagner, S., Cawley, K. M., Rosario-Ortiz, F. L. \& Jaffe, R. In-stream sources and links between particulate and dissolved black carbon following a wildfire. Biogeochemistry 124, 145-161 (2015).

21. Dittmar, T. et al. Continuous flux of dissolved black carbon from a vanished tropical forest biome. Nat. Geosci. 5, 618-622 (2012).

22. Marques, J. S. J. et al. Dissolved black carbon in the headwaters-to-ocean continuum of Paraiba Do Sul River, Brazil. Front. Earth Sci. 5, 12 (2017).

23. Ding, Y., Yamashita, Y., Dodds, W. K. \& Jaffe, R. Dissolved black carbon in grassland streams: is there an effect of recent fire history? Chemosphere $\mathbf{9 0}$, 2557-2562 (2013).

24. Hanke, U. M. et al. What on earth have we been burning? Deciphering sedimentary records of pyrogenic carbon. Environ. Sci. Technol. 51, 12972-12980 (2017).

25. Singh, N. et al. Transformation and stabilization of pyrogenic organic matter in a temperate forest field experiment. Glob. Change Biol. 20, 1629-1642 (2014).

26. Myers-Pigg, A. N. et al. Labile pyrogenic dissolved organic carbon in major Siberian Arctic rivers: implications for wildfire-stream metabolic linkages. Geophys. Res. Lett. 42, 377-385 (2015).

27. Richey, J. E. et al. Water discharge and suspended sediment concentrations in the Amazon River: 1982-1984. Water Resour. Res. 22, 756-764 (1986). 
28. Moreira-Turcq, P., Seyler, P., Guyot, J. L. \& Etcheber, H. Exportation of organic carbon from the Amazon River and its main tributaries. Hydrol. Process. 17, 1329-1344 (2003).

29. Richey, J. E. et al. Biogeochemistry of carbon in the Amazon River. Limnol. Oceanogr. 35, 352-371 (1990).

30. Davidson, E. A. et al. The Amazon basin in transition. Nature 481, 321 (2012).

31. Park, E. \& Latrubesse, E. M. Modeling suspended sediment distribution patterns of the Amazon River using MODIS data. Remote Sens. Environ. 147, 232-242 (2014).

32. Ward, N. D. et al. The compositional evolution of dissolved and particulate organic matter along the lower Amazon River-Óbidos to the ocean. Mar. Chem. 177, 244-256 (2015).

33. Wiedemeier, D. B. et al. Characterization, quantification and compoundspecific isotopic analysis of pyrogenic carbon using benzene polycarboxylic acids (BPCA). J. Vis. Exp. https://doi.org/10.3791/53922 (2016).

34. Dittmar, T. \& Koch, B. P. Thermogenic organic matter dissolved in the abyssal ocean. Mar. Chem. 102, 208-217 (2006).

35. Roebuck, J. A., Seidel, M., Dittmar, T. \& Jaffe, R. Land use controls on the spatial variability of dissolved black carbon in a subtropical watershed. Environ. Sci. Technol. 52, 8104-8114 (2018).

36. Sleighter, R. L. \& Hatcher, P. G. The application of electrospray ionization coupled to ultrahigh resolution mass spectrometry for the molecular characterization of natural organic matter. J. Mass Spectrom. 42, 559-574 (2007).

37. Ding, Y., Yamashita, Y., Jones, J. \& Jaffe, R. Dissolved black carbon in boreal forest and glacial rivers of central Alaska: assessment of biomass burning versus anthropogenic sources. Biogeochemistry 123, 15-25 (2015).

38. Jones, M. W. et al. Environmental Controls on the riverine export of dissolved black carbon. Glob. Biogeochem. Cycles 33, 849-874 (2019).

39. Jiménez-Muñoz, J. C. et al. Record-breaking warming and extreme drought in the Amazon rainforest during the course of El Niño 2015-2016. Sci. Rep. 6, 33130 (2016).

40. Park, E. \& Latrubesse, E. M. The hydro-geomorphologic complexity of the lower Amazon River floodplain and hydrological connectivity assessed by remote sensing and field control. Remote Sens. Environ. 198, 321-332 (2017).

41. Bao, H., Niggemann, J., Huang, D., Dittmar, T., \& Kao, S.-J. et. al. Different responses of dissolved black carbon and dissolved lignin to seasonal hydrological changes and an extreme rain event. Jor. Geophys. Res. 124, 479-493 (2019).

42. Albéric, P. et al. Variation of the isotopic composition of dissolved organic carbon during the runoff cycle in the Amazon River and the floodplains. C. $R$. Geosci. 350, 65-75 (2018).

43. Mayorga, E. et al. Young organic matter as a source of carbon dioxide outgassing from Amazonian rivers. Nature 436, 538-541 (2005).

44. Shrivastava, M. et al. Urban pollution greatly enhances formation of natural aerosols over the Amazon rainforest. Nat. Commun. 10, 1046 (2019)

45. Cirino, G. et al. Observations of Manaus urban plume evolution and interaction with biogenic emissions in GoAmazon 2014/5. Atmos. Environ. 191, 513-524 (2018)

46. Bouchez, J. et al. Turbulent mixing in the Amazon River: the isotopic memory of confluences. Earth Planet. Sci. Lett. 290, 37-43 (2010).

47. de Sá, S. S. et al. Contributions of biomass-burning, urban, and biogenic emissions to the concentrations and light-absorbing properties of particulate matter in central Amazonia during the dry season. Atmos. Chem. Phys. Discuss. 2019, 1-77 (2019)

48. Stubbins, A., Niggemann, J. \& Dittmar, T. Photo-lability of deep ocean dissolved black carbon. Biogeosciences 9, 1661-1670 (2012).

49. Wagner, S. \& Jaffe, R. Effect of photodegradation on molecular size distribution and quality of dissolved black carbon. Org. Geochem. 86, 1-4 (2015).

50. Coppola, A. I., Ziolkowski, L. A., Masiello, C. A. \& Druffel, E. R. M. Aged black carbon in marine sediments and sinking particles. Geophys. Res. Lett. 41, 2427-2433 (2014).

51. Ding, Y., Watanabe, A. \& Jaffe, R. Dissolved black nitrogen (DBN) in freshwater environments. Org. Geochem. 68, 1-4 (2014).

52. Medeiros, P. M. et al. Fate of the Amazon River dissolved organic matter in the tropical Atlantic Ocean. Glob. Biogeochem. Cycles 29, 677-690 (2015).

53. Dittmar, T. \& Paeng, J. A heat-induced molecular signature in marine dissolved organic matter. Nat. Geosci. 2, 175-179 (2009).

54. Seidel, M. et al. Molecular-level changes of dissolved organic matter along the Amazon River-to-ocean continuum. Mar. Chem. 177, 218-231 (2015).

55. Park, E. \& Latrubesse, E. The Hydro-geomorphologic Complexity of the Lower Amazon River Floodplain and Hydrological Connectivity Assessed by Remote Sensing and Field Control. Remote Sens. Environ. 198, 321-332 (2017).

56. Dittmar, T., Koch, B., Hertkorn, N. \& Kattner, G. A simple and efficient method for the solid-phase extraction of dissolved organic matter (SPE-DOM) from seawater. Limnol. Oceanogr.-Methods 6, 230-235 (2008).
57. Seidel, M. et al. Biogeochemistry of dissolved organic matter in an anoxic intertidal creek bank. Geochim. Cosmochim. Acta 140, 418-434 (2014).

58. Riedel, T. \& Dittmar, T. A method detection limit for the analysis of natural organic matter via Fourier transform ion cyclotron resonance mass spectrometry. Anal. Chem. 86, 8376-8382 (2014).

59. Koch, B. P. \& Dittmar, T. From mass to structure: an aromaticity index for high-resolution mass data of natural organic matter. Rapid Commun. Mass Spectrom. 20, 926-932 (2006).

60. Koch, B. P. \& Dittmar, T. From mass to structure: an aromaticity index for high-resolution mass data of natural organic matter (vol 20, pg 926, 2006). Rapid Commun. Mass Spectrom. 30, 250-250 (2016).

61. vegan: Community Ecology Package. v. R package version 2.5-2 (2018).

62. R: A language and environment for statistical computing (Vienna, Austria, 2018).

63. Coppola, A. I., Walker, B. D. \& Druffel, E. R. M. Solid phase extraction method for the study of black carbon cycling in dissolved organic carbon using radiocarbon. Mar. Chem. 177, 697-705 (2015). Part 5.

64. Ziolkowski, L. A. \& Druffel, E. R. M. The feasibility of isolation and detection of fullerenes and carbon nanotubes using the benzene polycarboxylic acid method. Mar. Pollut. Bull. 59, 213-218 (2009).

65. Ziolkowski, L. A., Chamberlin, A. R., Greaves, J. \& Druffel, E. R. M. Quantification of black carbon in marine systems using the benzene polycarboxylic acid method: a mechanistic and yield study. Limnol. Oceanogr. Methods 9, 140-149 (2011)

66. Hammes, K. et al. Comparison of quantification methods to measure firederived (black/elemental) carbon in soils and sediments using reference materials from soil, water, sediment and the atmosphere. Glob. Biogeochem. Cycles 21, https://doi.org/10.1029/2006gb002914 (2007).

67. Lang, S. Q., Früh-Green, G. L., Bernasconi, S. M. \& Wacker, L. Isotopic ( $\delta 13 \mathrm{C}$, $\Delta 14 \mathrm{C}$ ) analysis of organic acids in marine samples using wet chemical oxidation. Limnol. Oceanogr.: Methods 11, 161-175 (2013).

68. Hanke, U. M. et al. Comprehensive radiocarbon analysis of benzene polycarboxylic acids (BPCAs) derived from pyrogenic carbon in environmental samples. Radiocarbon 1-14, https://doi.org/10.1017/ RDC.2017.44 (2017)

69. Lang, S. Q., Bernasconi, S. M. \& Früh-Green, G. L. Stable isotope analysis of organic carbon in small ( $\mu \mathrm{g} \mathrm{C})$ samples and dissolved organic matter using a GasBench preparation device. Rapid Commun. Mass Spectrom. 26, 9-16 (2012).

70. Ward, N. D. et al. Velocity-amplified microbial respiration rates in the lower Amazon River. Limnol. Oceanogr. Lett. 3, 265-274 (2018).

71. Mayorga, E., Logsdon, M. G., Ballester, M. V. R. \& Richey, J. E. LBA-ECO CD 06 Amazon River Basin Land and Stream Drainage Direction Maps. ORNL DAAC, Oak Ridge, Tennessee, USA. https://doi.org/10.3334/ORNLDAAC/ 1086 (2012).

72. Beck, H. E., Roo, Ad \& Dijk, A. I. J. Mv Global maps of streamflow characteristics based on observations from several thousand catchments. $J$. Hydrometeorol. 16, 1478-1501 (2015).

73. Center for International Earth Science Information Network-CIESINColumbia University, International Food Policy Research Institute-IFPRI, The World Bank \& Centro Internacional de Agricultura Tropical-CIAT (NASA Socioeconomic Data and Applications Center (SEDAC), Palisades, NY, 2017).

74. van der Werf, G. R. et al. Global fire emissions estimates during 1997-2016 Earth Syst. Sci. Data 9, 697-720 (2017)

75. Collins, W. J. et al. Development and evaluation of an Earth-System modelHadGEM2. Geosci. Model Dev. 4, 1051-1075 (2011).

76. Jones, C. D. et al. The HadGEM2-ES implementation of CMIP5 centennial simulations. Geosci. Model Dev. 4, 543-570 (2011).

77. Bellouin, N. et al. Aerosol forcing in the Climate Model Intercomparison Project (CMIP5) simulations by HadGEM2-ES and the role of ammonium nitrate. J. Geophys. Res.-Atmos. 116, https://doi.org/10.1029/2011jd016074 (2011).

78. Bond, T. C. et al. Bounding the role of black carbon in the climate system: a scientific assessment. J. Geophys. Res.-Atmos. 118, 5380-5552 (2013).

79. van Leeuwen, T. T. et al. Biomass burning fuel consumption rates: a field measurement database. Biogeosciences 11, 7305-7329 (2014).

80. Akagi, S. K. et al. Emission factors for open and domestic biomass burning for use in atmospheric models. Atmos. Chem. Phys. 11, 4039-4072 (2011).

81. Olson, D. M. et al. Terrestrial ecoregions of the world: a new map of life on earth: a new global map of terrestrial ecoregions provides an innovative tool for conserving biodiversity. BioScience 51, 933-938 (2001).

82. Ramankutty, N., Evan, A. T., Monfreda, C. \& Foley, J. A. Farming the planet: 1. Geographic distribution of global agricultural lands in the year 2000. Glob. Biogeochem. Cycles 22, https://doi.org/10.1029/2007gb002952 (2008). 
83. van der Werf, G. R. et al. Global fire emissions and the contribution of deforestation, savanna, forest, agricultural, and peat fires (1997-2009). Atmos. Chem. Phys. 10, 11707-11735 (2010).

84. Lamarque, J. F. et al. Historical (1850-2000) gridded anthropogenic and biomass burning emissions of reactive gases and aerosols: methodology and application. Atmos. Chem. Phys. 10, 7017-7039 (2010).

85. Granier, C. et al. Evolution of anthropogenic and biomass burning emissions of air pollutants at global and regional scales during the 1980-2010 period. Clim. Change 109, 163-190 (2011)

86. Diehl, T. et al. Anthropogenic, biomass burning, and volcanic emissions of black carbon, organic carbon, and SO2 from 1980 to 2010 for hindcast model experiments. Atmos. Chem. Phys. Discuss. 2012, 24895-24954 (2012).

\section{Acknowledgements}

We thank Michael Hilf for assistance in the laboratory. We also thank Derek Vance, Chantal Freymond, and the crew onboard the Joao Felipe (November 2015) for assistance, organization, and coordination of collecting river water samples. We thank Ilja van Meerfeld for comments on an earlier version of the manuscript and helpful discussions. We also thank Katrin Klaproth (University of Oldenburg) for support with the FT-ICRMS analysis. We thank Lukas Wacker and the staff of ETH Laboratory of Ion Beam Physics for AMS support. We thank Madalina Jaggi for support with $\delta^{13} \mathrm{C}$ measurements. We thank Ben Johnson (UK Met Office) for generating the aerosol BC deposition grids by running the HadGEM2-ES model. We thank Ellen Druffel for comments on the manuscript. A.I.C. thanks Natalie Renier (WHOI Media Team) for support in making Fig. 1. A.I.C. acknowledges financial support from the University of Zurich Forschungskredit Fellowship and the Science Faculty of the University of Zurich (No. STWF-18-026). S.A. and A.I.C. acknowledges support from SNSF \#200021_178768. M.W.I.S. acknowledges support for the University Research Priority Program: Global Change and Biodiversity. J.E.R. and N.D.W. acknowledges financial support from NSF DEB Grant \#1256724 and FAPESP Grant \#08/58089-9.

\section{Author contributions}

A.I.C., M.W.I.S., T.D. and T.I.E. led efforts in devising the study objectives and design of the work. A.I.C. conducted concentration and isotopic measurements of DOC and DBC, analyzed data, interpreted the data and wrote the paper. G.S. collected samples. B.N.R. coordinated traveling logistics to Brazil. N.H. provided support and quality control with $\mathrm{DBC}$ and $\mathrm{DOC}{ }^{14} \mathrm{C}$ measurements and radiocarbon corrections. S.A. provided input with discussions. M.S. and T.D. added FT-ICR-MS measurements, associated data analyses and scientific interpretation. D.V., J.E.R. and N.D.W. provided support for hydrology context. N.D.W. and J.E.R. provided river gauge data, hydrological expertize, input on the interpretation of the data and substantively revised the manuscript. D.V. provided discharge, land use, and urbanization catchment-specific data. M.W.J. provided outputs of atmospheric BC deposition from the HadGEM2-ES model and input for the interpretation of the data. All authors provided comments in constructing the final version of the manuscript.

\section{Additional information}

Supplementary Information accompanies this paper at https://doi.org/10.1038/s41467019-11543-9.

Competing interests: The authors declare no competing interests.

Reprints and permission information is available online at http://npg.nature.com/ reprintsandpermissions/

Peer review information: Nature Communications would like to thank Michael I Bird, Yan Ding, and other, anonymous, reviewers for their contributions to the peer review of this work. Peer review reports are available.

Publisher's note: Springer Nature remains neutral with regard to jurisdictional claims in published maps and institutional affiliations.

(c) Open Access This article is licensed under a Creative Commons Attribution 4.0 International License, which permits use, sharing, adaptation, distribution and reproduction in any medium or format, as long as you give appropriate credit to the original author(s) and the source, provide a link to the Creative Commons license, and indicate if changes were made. The images or other third party material in this article are included in the article's Creative Commons license, unless indicated otherwise in a credit line to the material. If material is not included in the article's Creative Commons license and your intended use is not permitted by statutory regulation or exceeds the permitted use, you will need to obtain permission directly from the copyright holder. To view a copy of this license, visit http://creativecommons.org/ licenses/by/4.0/.

(c) The Author(s) 2019 